\title{
The Role of Intra-Group Consensus-Building in Disarming Militant Groups in Northern Ireland
}

\section{Benedetta Berti, Ariel Heifetz Knobel, \& Gary Mason}

\begin{abstract}
This study examines the internal process that led combatant groups in Northern Ireland, focusing on the Loyalist camp, to relinquish armed struggle as a viable strategy to accomplish their political goals. The study focuses on internal dynamics, i.e. intra-group negotiations and consensus- building mechanisms that Loyalist militant organisations employed to switch from violence to non-violence and from confrontation to engagement with their enemies. The paper underlines how the consensus- building process was multi-layered and included a combination of carefully structured internal consultations amongst combatants, together with the crafting and implementation of targeted programs to empower and transform militant organisations and their role within society. The chapter also focuses on the specific roles both ex-prisoners and key faith leaders played in shaping this monumental transformation. Finally, through in- depth case study analysis, the authors examine the main lessons that can be learned from the consensus-building process among Northern Irish Loyalist combatants and discuss its relevance to other intractableconflicts.

This paper is based on the chapter "Disarming Militant Groups from Within: Building Support for Peace amongst Combatants in Northern Ireland," in: Negotiations in Times of Conflict, Sher, G., Kurz, A., (eds.); Tel Aviv: Institute for National Security Studies, forthcoming.
\end{abstract}

\section{Keywords}

Consensus-building, disarming militant group, Northern Ireland, peace-making

\section{The Importance of Intra-Group Consensus-Building in Peace-Making}

"Following a direct engagement with all the units and departments of our organisation, the leadership of the Ulster Volunteer Force and Red Hand Commando today make public the outcome of our three-year consultation process.... as of 12 midnight, Thursday 3 May 2007, the Ulster Volunteer Force and Red Hand Commando will assume a non-military, civilianised role." (Ulster Volunteer Force 
Endgame Statement 2007)

In 2007, the three main Loyalist militant groups in Northern Ireland-the Ulster Volunteer Force (UVF), the Ulster Defence Association (UDA), and the Red Hand Commando (RHC) announced their transformation from military to civilian/political organizations. They all subsequently handed over the vast majority of their weapons.

The issue of how militant organisations shed their violent ways and adopt a constructive civilian role within their communities is a crucial one and intimately related to the relatively under-explored topic of how to conduct internal negotiations within, rather than between, communities.

Indeed, whilst a large part of the negotiation and conflict resolution literature focuses on the content and process of negotiations between "warring parties," less attention has been generally devoted to understanding the processes of consultation and consensus-building within a given side. Yet, these internal processes are just as vital as the official ones taking place between warring parties (Lilja 2012).

The lack of solid backing from a leader's constituency in general and in this case, from the combatant community, can jeopardise and ultimately kill a peace process before, during, and after interparty negotiations. Firstly, sitting at the negotiating table without such coordination and support substantially increases the chances of these actors deciding to intervene to sabotage the political process.

Secondly, when militant members are alienated from their leadership, this can result in defections to more radical groups or in the creation of irredentist splinter groups. Such factionalism is extremely dangerous as internal disagreement is not at all synonymous with the decline in the use of violence as a strategy, and —as aptly explained by Martha Crenshaw — "splits and merger are a form of propagation of terrorism" (Crenshaw 1991: 80-1).

Thirdly, when a given organisation sits at the negotiating table against the wishes of its own constituency and combatants, it finds itself more restricted in its capacity to make significant concessions, as 'giving in' would risk igniting additional internal conflict and further weaken the group's cohesion and status (Moore et al, 2013).

Finally, lack of intra-group consensus complicates efforts to implement any peace agreement, while also making such arrangements more fragile and less likely to endure.

Therefore, for broader inter-party peace negotiations to succeed, it is absolutely vital for the main actors involved, both at the state and non-state level, to look inwardly and to invest on building consensus internally and within the broader communities that support them. Consensus-building is by no means a one-time trick; it is instead a relational and dynamic process that requires constant interaction between the leadership and the supporting bases as well as a strategic and long-termapproach.

Looking at the Northern Ireland conflict, the post-agreement consensus-building process for non-violence and disarmament was just as crucial (if not more) as the pre- 1998 mobilisation to support official peace negotiations, given its aim - to embed a permanent nonviolent strategy and to transform the role of combatants within society—was ambitious yet essential to shift from conflict to both engagement and coexistence in a shared society. The process did not end with the definitive decommissioning of both sides, rather it evolved from embedding non-violence to transforming societal 
and personal relations within Northern Ireland, moving a little farther down the long and winding road to reconciliation.

\section{The Transformation of Loyalism in Northern Ireland: From Armed Struggle to Engagement to Disarmament to Reintegration}

On Good Friday, 10 April 1998, after 800 years of conflict on the island of Ireland, eighty years of partition, and thirty years of the Northern Irish "Troubles," in which over 3,600 people were killed, over 35,000 injured, 34,000 shootings and 14,000 bombings (in a population of only 1.7 million people), the official negotiations concluded with the Belfast or "Good Friday" Agreement (GFA).

Since the late 1960s, Northern Ireland had become the stage of a bloody internal conflict between Republicans and Loyalists. At its core, the conflict saw two separate, non-integrated populations fight over radically different and mutually exclusive political ideals: the reunification of Ireland (ending British sovereignty over Northern Ireland) versus the permanent integration of Northern Ireland into the United Kingdom (based on the 1921 partition of the island). The Nationalist and Republican communities (mostly Catholic) identify as Irish and seek an all-island Republic of Ireland, while the Unionist and Loyalist communities (mostly Protestant) identify as British, loyal to the United Kingdom. In addition, the tensions were fuelled by the deeply unequal nature of the political, social, and economic systems which de facto placed the Catholic community in a state of structural discrimination, political underrepresentation, and economic marginalisation.

Getting to "yes" was no easy task, and implementing the GFA has been an accomplishment of monumental proportions, especially given the challenge of keeping spoilers at bay—such as Republican and Loyalist violent splinter groups (McKittrick and McVea 2001: 331). Nevertheless, the agreement, ratified by popular referendum in May 1998, recognised the right to self-determination for all people in Northern Ireland and established local political institutions on the basis of power-sharing principles. All the main militant organisations-- the Irish Republican Army (IRA), Irish National Liberation Army (INLA) which joined after the referendum, and the UDA, UVF, and RHC--maintained their commitment to the peace process while preserving cohesion and preventing mass-scale defections (Heifetz Knobel 2011).

To be sure, the Good Friday Agreement did not solve all of Northern Ireland's conflict-related problems, and in the post-agreement decade, these organisations embarked on a long and difficult process of disarmament (“decommissioning”). In this context, the main task for combatant communities shifted from preventing spoilers to re-integrating former militants.

Keeping the combatant community on board while committing to a ceasefire, to peace negotiations, and finally to renunciation of armed struggle was pivotal in the Northern Ireland transition. For both Republicans and Loyalists militants, their experience as fighters had taught them resentment and distrust towards their 'enemy,' thus, for them, the psychological leap from conflict to engagement was an especially hard one to make. More substantially, combatants, especially if on a full- time basis, can often 
have direct incentives to continue fighting, as it may provide their economic livelihood along with a sense of identity, belonging, and prestige.

For Loyalists, building consensus for the peace process began nearly 10 years before the agreement, when combatants themselves began challenging their organisation's use of force as an effective strategy. Loyalist leaders employed multiple strategies to gain buy-in from their members throughout the pre- and post-agreement phases. Some of the most prominent ones are reviewed here.

\section{Internal and External Agents of Change: the Role of Ex-Prisoners and Key Faith Leaders as Combatants" "Critical}

Friends"

Former Loyalist prisoners played, and continue to play, a key role in reformulating their organisations' strategies: when the first life-sentenced prisoners were released in Northern Ireland in 1989 and the early 1990s, they reflected on the personal and community price paid to sustain armed struggle, with the credibility and legitimacy "to ask questions and be heard" (Hoey 2010). They re-entered their communities challenging the Loyalist ideology and its use of force, and publicly criticizing the British State, saying things like "I served 15 years to preserve the British state, and it was the British state that put me in prison. What does that say about our battle? About our political ideology?" These questions and focus on the human cost of the conflict within working class Loyalist communities "began to influence change" (Watters 2010).

In the years preceding the GFA, while Loyalists enforced their 1994 ceasefire and policy of 'restraint,' intra-group discussions focused increasingly on building support for engagement with the enemy. Ex-prisoners continued questioning the use of violence but in a more permanent way, asking whether it was "really helping to transform Loyalist communities." Such discussions gradually eroded "the old-school" ethos of other combatants in the community (Watters 2010).

In addition to these internal agents of change, there were about a dozen clergy members on the entire island who directly engaged militants and those committed to violence (Mason 2010). Aiding the peace process from the outside, their contributions took the form of transferring messages as intermediaries, facilitating private meetings, and assisting "political groups to evaluate their strategies and goals" (McCartney 1999). These roles continue even today.

The third function is most relevant to the process of consensus-building within Loyalist militant groups. Beginning in the early 1990s, a few local Protestant clergies began serving as same-side proponents within Loyalism. For example, Reverends Roy Magee and Harold Good supported leading peace-making loyalists in their questioning of the philosophy and morality of violence" (Corry 2007: 9). Methodist Reverend Gary Mason, whom the UVF and RHC today consider a "critical friend," worked for 27 years in the inner city of Belfast and promoted urban, social, and economic development as a way to serve Loyalism by arguing, "we can do it better" (while most Protestant clergy chastised Loyalist combatants and former combatants) (Mason 2010). Still today, Mason listens to combatants and excombatants, affirms their pain, and talks with them about accountability, forgiveness, and new beginnings. 
He accompanies them in unfamiliar contexts where they are invited to share their stories or listen to others. He facilitates meaningful engagement both among Loyalists and with their traditional adversaries, such as other combatant groups, politicians, victim's groups, and security services.

The influence of critical friends like Mason is bolstered by their understanding that even a reverend or priest could have taken the path that the militants took, yet they are scrutinized for "talking to men of violence." In Mason's words: "I am well aware of the risks that one can be seen to be endorsing violence or at least giving violence credibility. But my role is one of engagement, not endorsement. I firmly believe that the person of faith in any religious tradition should be taking risks for peace that politicians simply can't take because of their political supportbase."

Because the positive contribution of former combatants is often unrecognized and excluded from the official 'peace process' story, the work of critical friendship is even more essential for affirming their dramatic journeys to peace.

\section{Tools to build support for ceasefires and for entering peace negotiations(1992-8): Explanation, Reframing, Consultation}

Throughout the 1990s Loyalist leaders were able to convince their members to observe a ceasefire and then to favour peace negotiations with the IRA by first explaining and reframing the enemy behaviour. This was possible due to the increased understanding that senior Loyalists, particularly exprisoners, had about the other side. Having been exposed to Republicans while incarcerated, these Loyalists were able to think analytically about the IRA and Sinn Fein, whereas most members viewed them as monolithic (Moloney 2010, 408). Additionally, in the early and mid-1990s, clergy-facilitated backchannels as well as NGO-facilitated workshops and dialogues gave senior militants further insight into the internal dynamics of their enemies (White 2010; Reynolds 2010). They understood (or felt they understood) how the other side was functioning, and they used this information to keep their members on board by explaining and reframing the actions of their enemy.

For example, following the 1998 peace agreement, when Loyalists heard Sinn Fein leader Gerry Adams' rhetoric flare up, UVF leaders explained to their members that such comments from Republican politicians were only meant "to keep their own people on board," stressing that people “shouldn't pay much attention” (Roberts 2010).

In addition to explaining negative gestures of their enemies, Loyalist leaders also reframed positive actions in order to sell the transition towards peace internally. For example, when the IRA finally declared its "cessation" of armed activities in August 1994, the Loyalist organisations framed it as "surrender" in order to justify their own subsequent ceasefire (Wilson 2010). The perceived victory served to convince those members who were pessimistic about the IRA's intentions, as well as to maintain internal legitimacy.

Also, preceding the 1994 ceasefire, a key tool to help minimise the chance of Loyalist spoilers, was consultation with the prison population. The Combined Loyalist Military Command (representing the UVF, UDA, and RHC) insisted on gaining access to prisons "to persuade and explain (Rowan 1995: 134- 
5) to their inmate counterparts, "before any decision would be taken." The UVF systematically held briefings with its prisoners. In 1994, with the help of Reverend Roy Magee, Loyalist politicians from the Ulster Democratic Party and Progressive Unionist Party (political proxies of the UDA and UVF, including some wanted "terrorists" visited Long Kesh prison to meet with their counterparts. (Rowan 1995: 119-20)

One result was a public letter endorsing the ceasefire and budding peace process, written by UDA and UFF prisoners. By the time the CLMC held its final meeting to approve the famous ceasefire "all segments of Loyalism were present: prisoners, combatants on the outside, wailers in the community, and nobody dissented" (Smith 2010).

It is worth noting that the practice of internal strategy discussions and consultation with the wider membership of Loyalist organisations continued well beyond the 1994 ceasefire and the 1997-8 peace process. Nearly a decade later, the UVF conducted 3 years of so-called "Roadshows" leading up to disarmament. This systematic approach involved leaders fanned out across Northern Ireland and Britain who met with local branches in order to explain the reasoning and importance of decommissioning the organisation's weapons and to ensure support for the act. Finally, in 2009, the organisation handed over its weapons arsenal to the satisfaction of the International Commission on Decommissioning (Heifetz Knobel 2011).

\section{Tools for building support for a permanent unarmed strategy (1990s - present): Reframing, Political Empowerment,}

\section{Community Development}

Reframing nonviolence as a continuation of the armed struggle was a key face-saving mechanism for Loyalist leaders to build support for long-term peace.

The 1994 prisoners' letter mentioned above emphasised the strategic nature of their shift away from violence: "To continue our military campaign under the present circumstances could be counterproductive and in the long term detrimental to our cause" (Rowan 1995: 120). A decade after the peace agreement, this rationale continues, as exemplified by the 2007 endgame statements of all the main Loyalist groups: The UDA stated: "the battle flags of the UFF will be furled in a hope that they may never have to see light of day again, but stand in readiness." (Ulster Defence Association Endgame Statement 2007). For the UVF and RHC, violence was no longer relevant because "the Union remains safe" as "the mainstream Republican offensive has ended" (Ulster Volunteer Force Endgame Statement 2007). This new framing of violence and its role allowed combatants to preserve the legitimacy of the armed struggle (not denouncing it) while effectively shelving it in favour of an unarmed strategy.

At the same time, moving towards permanent non-violence required a deep investment to reintegrate former combatants and empower their own working class Loyalist communities. CLMC leader Plum Smith describes the importance of institutional politics for peace-making this way: "Loyalists saw political empowerment as the only way out" (Smith 2010). 
After the ceasefires, EU peace funding came to Northern Ireland, and ex-prisoner's initiatives grew (unnamed Loyalist 2010) with ex-combatant volunteers setting up non-profits to improve socioeconomic conditions and to lobby state institutions.

An interesting example of such programs is the Action for Community Transformation (ACT), founded by UVF and RHC ex-combatants to be a "model of politicisation which supports the reintegration of former combatants in partnership with critical friends and the wider community." ACT was devised in 2007 and initially presented in small- scale consultations to senior militants, offering an alternative to the armed struggle and a model of conflict transformation. ACT's three-stage program aims at training former militants (from topics as diverse as mediation, adaptive leadership, media skills, and employment preparation), connecting them to organisations and networks for community development, and moving members more deeply into civic engagement through local politics and associations. Through its three phases, the ACT Initiative promotes "transformation," "positive active citizenship," and "collaboration with all elements of civic society." (The ACT Initiative Policy Document, undated)

As more ex-combatants moved into community development, the promise of socio- economic growth - especially inward investment and job creation - was an additional tool for persuading people away from violence, and in light of the rise of government economic packages. As one UVF ex-prisoner recalls: "we were told that the lack of investment in these areas was a result of the conflict, and people thought things would get better" (Roberts 2010). Thus, making peace "was a political process as much as it was an economic process" (Mason 2011).

\section{The Internal Road to Nonviolent Engagement: Lessons Learned}

Building consensus for peace negotiations, post-agreement implementation, and eventually disarmament amongst Northern Irish Loyalist communities was a multi- layered process: from the top-down, leaders invested in direct and indirect communication to their supporting bases to reframe the understanding of the conflict as well as of the advantages of pursuing a political, rather than armed, strategy. This was done by prominent, trusted and credible figures, especially well-known combatants and ex-prisoners. In addition to reframing, consensus-building also focused on internal consultations to improve the level of grassroots ownership in the strategy change and the commitment to its outcome. Finally, crafting short- and long- term political and social programs provided militants with alternatives to armed struggle, and greatly buttressed their willingness to relinquish theirweapons.

Looking at the experience of Northern Ireland and its applicability to other intractable conflicts, the consensus-building process underlines the following elements:

- Engagement: Integrate, rather than alienate, potential spoilers. The process of dialogue between communities and within communities requires a strategy of engagement with, and acknowledgement of, potential spoilers and their narratives.

- Reframe: Understand that your enemy may reframe your actions to look victorious. This allows him 
flexibility to move towards peace. Also use reframing as a face-saving tool to convince your own constituency that you are not abandoning your cause. In turn, this may allow both sides to frame the compromise as a 'victory' while also shifting strategy, without having to denounce the past.

- Promote grassroots ownership: Invest in direct communication and consultation with bases of support; actively seek to prepare people for peace. In doing so it is important to:

- Rely on internal" Agents of Change": Involve credible trust-worthy supporters like community leaders or former prisoners (where relevant);

- Involve external "Critical Friends" to support militant groups in sustaining their transition to 'civilianisation' and to facilitate communication with other actors.

- Develop the Community around Combatants: Offer alternative roles and ways to demonstrate loyalty. The process should focuson:

- Creating viable and sustainable re-integration programs that address former combatants' political identity, financial needs, and psychological well-being.

- "Decommission people's minds, not only their weapons" by providing combatants with non-violent social and community development approaches.

- Recognize that consensus-building for every step takes time: Consensus- building must be seen as continuous and dynamic processes (even 15 years' post-agreement), for implementation and beyond. The question should not just be how to sign an agreement, but also how to create conditions for negotiations and how to sustain that initial consensus for a peace agreement after it is signed. Thus, a longterm consensus-building strategy is needed.

While each of these points should be further developed and put into context, it is clear that peace-making in Northern Ireland represents an important and powerful legacy, as well as a cautious tale of hope with respect to managing and potentially resolving long-standing, embedded, and bitter internal conflicts.

Note: Interviews were conducted in June-August 2010 by Ariel Heifetz Knobel. 


\section{REFERENCES}

ACT Initiative Policy Document (Action for Community Transformation). [undated]. "Bone of our bone.

Flesh of our flesh" - A forum for former UVF/RHC political prisoners!

http://www.longkeshinsideout.co.uk/?page id=12

Corry, Geoffrey. (2007) 'Overview of Peace Process concepts from the Perspective of a Practitioner'.

Dublin. Unpublished essay.

Crenshaw, Martha. (1991) 'How Terrorism Declines' in C. McCauley (ed), Terrorism Research and Public

Policy, London, Frank Cass.

Heifetz Knobel, Ariel. (2011) 'A Palatable Reconciliation. From Violence to Politics in Ethno- National Conflict: Paramilitary Strategy Shift in Northern Ireland'. Unpublished MALD thesis. The Fletcher School of Law and Diplomacy, Tufts University.

Hoey, Paul. (2010) (former UVF Interlocutor to the International Commission on Decommissioning; Ulster Volunteer Force ex-prisoner). Interview with the author. Belfast, Northern Ireland. 18 Aug. Lilja, Jannie. (2012) 'Outbidding and the Decision to Negotiate' in I. William Zartman, Mark Anstey, and Paul Meerts (eds), The Slippery Slope to Genocide: Reducing Identity Conflicts and Preventing Mass Murder, Oxford Scholarship Online, DOI: 10.1093/acprof:oso/9780199791743.001.0001.

Mason, Gary. (2010) (Methodist Reverend of East Belfast Mission and intermediary to Loyalist paramilitaries). Interview with the author. Belfast, Northern Ireland. 12 Aug.

Mason, Gary. (2011) Militias in Northern Ireland: Guiding Combatants from Violence to Politics. [Public lecture at the Program on Negotiation] Harvard University. 11 Nov.

McCartney, Clem. (1999) The Role of Civil Society, in Accord Vol 8: Striking a Balance: The Northern Ireland Peace Process. Conciliation Resources. http://www.c-r.org/our- work/accord/northern-ireland/civilsociety.php.

McKittrick, David and David McVea. (2001) Making Sense of the Troubles. London, Penguin Books. Moloney, Ed. (2010) Voices from the Grave: Two Men's War in Ireland. New York, PublicAffairs Perseus Books Group.

Moore, Gavin, Neophytos Loizides, Nukhet A. Sandal \& Alexandros Lordos. (2014) Winning Peace Frames: Intra-Ethnic Outbidding in Northern Ireland and Cyprus, West European Politics, 37:1, 159-181. DOI: $10.1080 / 01402382.2013 .801576$

Reynolds, Gerry. (2010) (Catholic priest of Clonard Monastery and former intermediary to the IRA). Interview with the author. Belfast, Northern Ireland. 24 Aug.

Roberts, Tom. (2010) (director of Ex-Prisoners Interpretative Center; Ulster Volunteer Force exprisoner). Interview with the author. Belfast, Northern Ireland. 23 Aug.

Brian, Rowan. (1995) Bebind the Lines: the Story of the IRA and Loyalist Ceasefires. Belfast, Blackstaff Press. Smith, Plum. (2010) (co-founder of Red Hand Commando and ex-prisoner). Remarks made at Feile an Phobail public panel]. Conway Mill, Belfast. 3 Aug.

Ulster Defence Association Endgame Statement. (2007), 221 in Brian Rowan, How the Peace Was Won (2008) Dublin, Gill and Macmillan Press. 
Ulster Volunteer Force Endgame Statement. (2007) “UVF Statement in full,” BBC News, 3 May.

http://news.bbc.co.uk/2/hi/uk news/northern ireland/6618365.stm

Unnamed Loyalist. (2010) Interview with the author. Belfast, Northern Ireland. 23 Aug.

Watters, Debbie. (2010) (co-founder of Northern Ireland Alternatives and Member of Northern Ireland

Policing Board). Interview with the author. Belfast, Northern Ireland. 19 Aug.

White, Ian. (2010) (founder/director of International and Political Programmes, Glencree Center for

Peace and Reconciliation). Interview with the author. Wicklow, Ireland. 25 Aug.

Wilson, Jim. (2010) (former peace talks negotiator for Progressive Unionist Party; Red Hand Commando ex-prisoner). Interview with the author. Belfast, Northern Ireland. 16 Aug.

Dr. Benedetta Berti is a Kreitman post-doctoral fellow at Ben Gurion University, a research fellow at the Institute for National Security Studies (INSS) and the author of "Armed Political Organizations. From Conflict to Integration” (Johns Hopkins University Press, 2013).

Ariel Heifetz Knobel is an American-Israeli facilitator of Track 1.5 and Track 2 initiatives in Israel and the West Bank. For the past four years, she has been consulting to Northern Irish peacemakers on bringing best practices to the Middle East, having conducted extensive fieldwork in Belfast through the Harvard Program on Negotiation. She is the former Public Diplomacy Director at the Israeli Consulate to New England, holds an MA in International Negotiation and Conflict Management from The Fletcher School at Tufts University and a BA from Columbia University.

Rev. Dr. Gary Mason is the Director of the Journey towards Healing programme at the Northern Ireland Association of Mental Health (NIAMH). Prior to this appointment, Rev. Dr. Mason spent 27 years as a Methodist clergy person in Belfast and has played an instrumental role in the Northern Irish peace process. In addition, he has contributed to establishing the Skainos project, the largest faith-based urban redevelopment project in Western Europe as well as a model of co-existence and conflict transformation. He holds a $\mathrm{PhD}$ in Psychology from the University of Ulster, a graduate degree in Theology from Queens University, and a Bachelor's in Business Studies from the University of Ulster. 